\title{
Drought and desertification in Moroccan Pre-Sahara, Draa valleys: exploring from the perspective of young people
}

\author{
Ahmed KarmaouiD
}

\begin{abstract}
Background: Worldwide, the arid regions have been experiencing cyclical droughts and devastation due to land desertification. A multi-criteria approach was proposed to establish the relationship between these pressures and assess their impact on the socio-economical, physical, and biological resources. This method was applied at local scale in the palm grove of Draa valley in southeastern Morocco. This paper aims to assess the socio-ecological impacts of drought and desertification, to develop a set of impact indicators of each phenomenon, and explore the relationship between drought and desertification. A framework of analysis was developed based on data collected from a survey using samples of 580 questionnaires: 290 for desertification and 290 for drought. A Likert scale data analysis was applied and rating scales varies from Low, Middle, High, and Very High impact.

Results: The results depict that drought is considered a first-rate threat in this region. The findings indicated also a very strong link between drought and desertification. The area is currently suffering from drought followed by desertification and then inundation. Natural and human factors are in the origin of desertification.
\end{abstract}

Conclusions: A set of variables and common variables of drought and desertification were proposed to understand their impacts on well-being.

Keywords: Oasis desert, Climate change, Anthropogenic impacts, Soil, Water

\section{Introduction}

In the last 30 years, climate change has become real challenge. Whether at the global, regional or even local scale, climate change has affected perilously, the productive sectors such as agriculture and then the economy of vulnerable areas. Climate change increases drought events (Anderegg et al. 2013), which lead to increases in desertification (Wonkka et al. 2016). Economically, strong positive associations between desertification and the real agricultural Gross domestic product (GDP) were found (Ge et al. 2015). Equally, drought is a major climatic factor reducing agriculture worldwide (Seidel et al. 2016; Mittler 2006). The impact of climate change is accelerated by human pressure. Grazing density and land use changes are factors that affect desertification (Tervonen et al. 2015). Currently, there are several studies on desertification (Wang and Yan 2017;

Correspondence: karmaoui.ahmed@gmail.com

Ibn El-Mahdi Eljirari-Imam Ali, Southern Center for Culture \& Sciences (SCCS), Lycée Imam Ali, Bni Zouli, Zagora, Morocco
Christian and Dhinwa 2018; Tomasella et al. 2018; Zelnik et al. 2017) and on drought (Yang et al. 2018; Zhang et al. 2018; Wu et al. 2018; Greene 2018), but few studies on the relationship between the two.

Regarding the arid local scale of these two phenomena, the same impacts were recorded on soil productivity. In fact, in arid regions, the agro-pastoralist households are severely affected by the climatic shocks (Coppock 1994). This is due to the lack of studies particularly on adaptation and vulnerability process at the farm level mainly in developing countries (Lemmen and Warren 2004). However, several studies have explored the environmental vulnerability at sub-catchment scale; and the most significant one, is the use of the Environmental Vulnerability Index that has classified the Moroccan oasis as vulnerable to climate change (Karmaoui et al. 2014a, 2014b, 2015a and 2015b). Historically, the oasis zone of the region has suffered severe environmental risks such as desertification, siltation, soil salinity and recurrent droughts (Chelleri et al. 2014); Karmaoui et al. 2015d). 
This has affected the local population, forcing some family members to migrate to northern big cities. The migration of young people becomes a crucial strategy to adapt to drought and climate change impacts in order to support the stayed family members through financial transfers (Karanja Ng'ang'a et al. 2016; Karmaoui et al. 2015c)

According to Fallahzade and Hajabbasi (2012), the Oasis-Desert ecosystem is characterized by low precipitation, high salt concentration and formation of weak rate of organic matter. The land use has a positive influence on soil, water, $\mathrm{pH}$, soil nutrients, and soil salinity in the oasis-desert ecotone (Gong et al. 2015). At the border of the hyper-arid deserts, oases are considered transitional space forming the buffer zone. The evolution of such area is an indicator of the relationship between deserts and humid regions (RADDO 2011). In fact, it is a barrier against the advancement of the desert. In ecological terms, the oases are threatened by salinity and siltation; and these problems are exacerbated by harsh climate, overgrazing of natural vegetation and scarcity of water (Laouina 2006). Water is essential for controlling the soil and vegetation in arid zones (Kong et al. 2009).The impact of droughts, coupled with dam storage upstream, has reduced half of the palm trees in the study area, which was reported to be decreased from $4575 \mathrm{~km}^{2}$ to $1342 \mathrm{~km}^{2}$ (Benmohammadi et al. 2000).Wetlands are being converted into desert because of the effects of drought and the overuse of water due to human consumption. For example, 2028.16 ha (two thousand and twenty eight point sixteen hectares) of wetlands were transformed into desert due to overexploitation of water in Heihe River region in china (Jiang et al. 2014). In fact, water is essential for the development of oasis desert ecosystems (Genxu and Guodong 1999). The existence of oasis is largely determined by the presence of surface water from upstream and adequate amount of availability of ground water as reported by Li et al. (2014). However, in these arid regions, the scarcity of water is a serious issue caused by the overuse of water resources for agriculture and human activities (Shen et al. 2014). So agricultural water management can be an essential step in making tradeoffs of this kind of imbalance (Lu et al. 2015) indicating the increasing vulnerability of oasis ecosystem and soil fertility. Particularly, water balance is essential for the maintenance of healthy oasis ecosystem and in turn oasis ecosystem provides food and water, essential materials for life support system. Environmental vulnerability requires a long term management of resources with consideration of socio-economical and environmental systems. As stated by Long and Gerbe (2005), drought is among the most important processes resulting in desertification. Drought and desertification are the major factors that threaten the soil and water components of the ecosystem. The impact on Soil and water resources may lead to devastation of socioeconomic condition of the people of the area. So this study is quite relevant and justified from the point of view of understanding of the intricate relationship between drought and desertification.

Draa Valley suffers from drought that causes scarcity of water supply (for irrigation and drinking water). Consequently, desertification takes place and causes the loss of soil fertility, affects crop yield, threatens food security, and leads to economic losses. Then these vulnerable local people are forced to migrate to the big cities for employment and for livelihood.

\section{Objective}

The general objective of this paper is to provide the opinion of the young people about the relationship between drought and desertification and the identification of their main variables. The specific objectives are outlined.

- To identify the impact factors and common variables of drought and desertification in the study area.

- To assess the socio-ecological impacts of drought and desertification.

- To explore the relationship between drought and desertification.

\section{Material and methods}

\section{Study area}

This study was carried out at Ternata palm grove $\left(30^{\circ} \mathrm{N}\right.$, $\left.6^{\circ} \mathrm{W}\right)$, in middle Draa valley in southeastern Morocco (Fig. 1). This valley covers an area of more than 15,000 $\mathrm{km}^{2}$ and the land area of the oasis is about 26,000 ha.

The local economy depends on agriculture. The main sources of water are rains of the high Atlas Mountains, for irrigation by Draa Wadi. The main crops are palm trees and cereals. In this arid region, more than $70 \%$ of the local population depends on the agricultural sector. The majority of this population herds domestic animals, which provide them with meat and milk for sale, and donkeys for transport of agricultural products. This dependence makes this zone vulnerable to drought and desertification. The trend.

\section{Framework}

In order to assess the interactions and impacts of drought and desertification on the socio-economical, physical, biological resources of the region, a framework of analysis was developed based on data collected. The framework explains how the drought and desertification can affect or affected by the action or the response of the local population (Fig. 2). The biophysical and the social templates are highly dependent and influenced by climate change. The proposed framework including the main components and the related factors help to simplify the complexities and the interaction of all used elements or variables. In this 


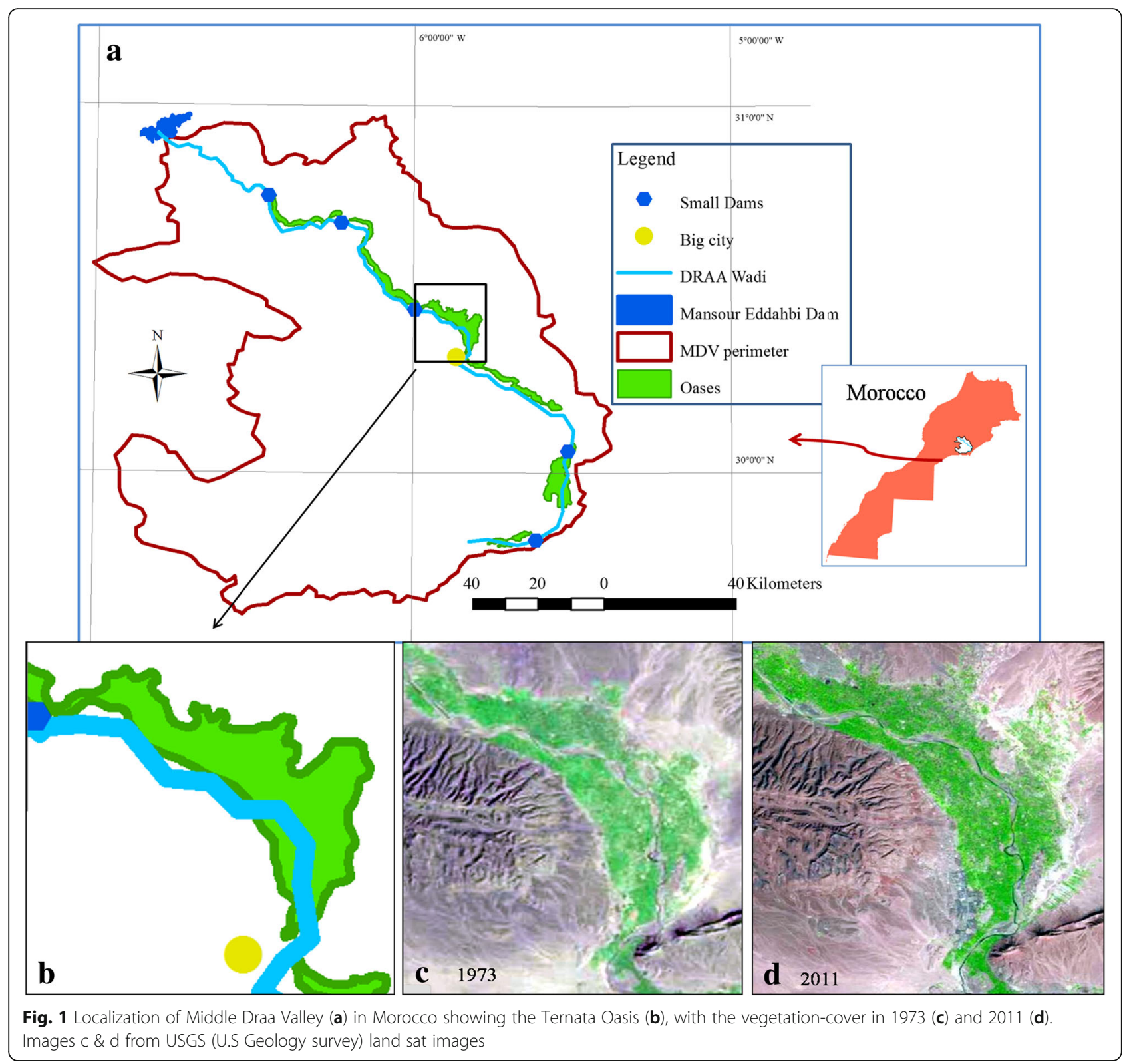

paper, the term "variable" was used to refer to a key element or a factor that change in value and the term "component" is an ensemble of variables of the same aspect. The approach determines the standards variables in the case of drought-desertification association and addresses how the used indicators are linked and interact.

Drought-desertification association has received little attention despite its ecological and socio-economical influence. These phenomena are major environmental problems and in steadily increase leading socio-economic damages and losses of biodiversity. Reduction risk in is lacking for most regions of Morocco including the oasis region. A Community-based Risk Reduction Framework (CRRT) was proposed (Fig. 2). This method uses an interdisciplinary approach that enhances community response toward the drought-desertification. The approach is used based on young people participation in the quantification of the impact factors and the elaboration of coping and planning strategies and the implementation.

It is possible to measure a determined variable using several methods. In this paper, the survey was used to provide the approximate value of the indicator and does not intend to cover all kind of indicators.

\section{Data collection and sample selection}

To better simplify the association between drought and desertification through the quantification of social, physical, economic, and ecological anthropogenic variables, data was collected using a structured questionnaire as mentioned in the Additional file 1. The survey was 


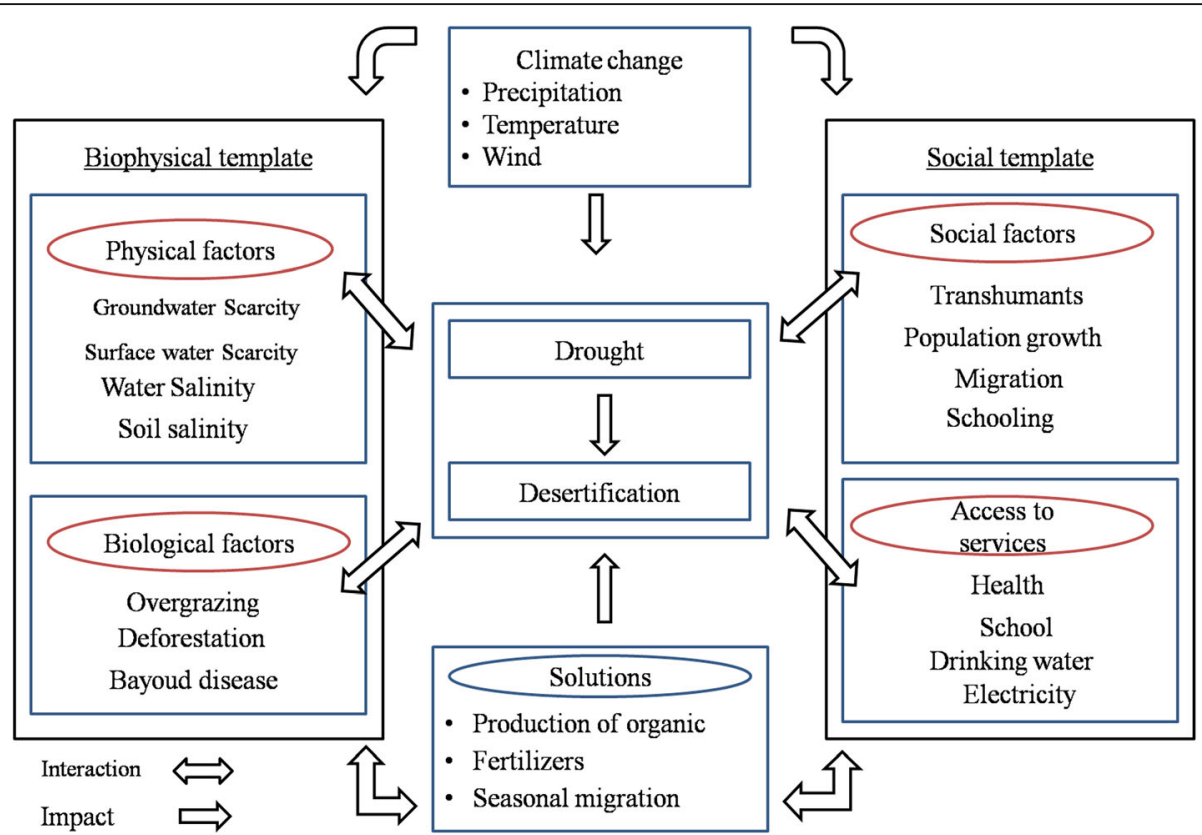

Fig. 2 Community-based risk reduction Framework identifying the indicators and their associations

conducted between 2015 and 2016 in Draa Valley. Supplemented data was gathered from the available literature. Interviews were conducted on young people in the rural area. Six villages were selected from nearest palm grove of Zagora the big city. The selected villages are the major sites of the rural area from which the major part of students are native. Two hundred ninety (290) age from 15 to 20 high school students were selected from these villages, and two types of questionnaires were filled (on desertification with 27 questions and the second on drought with 29 questions).

The questionnaire was administered by class of $30 \mathrm{stu}$ dents of the Ibn El Mahdi Eljirari high school during 15 days distributed on 2 years carried out by the first author. The investigation in this period was supported by high school administration and the Student's parents association who authorized completion.

\section{Data analysis}

In measuring drought and desertification, the concept of vulnerability combines ecological, economical, and social factors. For this reason, a set of variables related to different sectors (a multidisciplinary approach) have been used. The compiled data was analyzed using Arab processor in social statistics software (APSS). The attitude measurement technique developed by Likert (1932), called Likert scale was used. This scale analysis was applied to measure young people's attitude and knowledge towards the drought and desertification phenomena. Twenty nine questions and selected 17 common questions were established. Each question involved the choice of one of the following response, Low, Middle, High, and Very High impact.

The used range of numerical values can range in a specific interval. Likert (1932) scaling most often uses five points. However, Thurstone's (1928) uses 11 points. The number of points on rating scales varies widely (Krosnick and Presser 2010). After determining the range of numerical values which $1-4$ in the current study. Each value gives the weight of the response. In this study, for example, the total number of interviewees is 290 for each type of phenomenon and the scale interval is $1=$ Low, $2=$ Middle, $3=$ High, and $4=$ Very High impact.

An example of application for drought phenomenon, for the first indicator, Groundwater Scarcity was given (Fig. 3).

Pearson's Correlation Coefficient was used to explore the relationship between drought and desertification and some socioeconomic characteristics, with significance at 0.05. The equation of the Pearson correlation coefficient (Pearson 1895) is as follows.

$$
r=\frac{1}{n-1} \sum \frac{\left(x_{i}-\bar{X}\right)\left(y_{i}-\bar{Y}\right)}{s_{x} s_{y}}
$$

With $\mathrm{X}$ and $\mathrm{Y}$, the variables, $\bar{X}$ and $\bar{Y}$, their averages, and $S_{x}$ and $S_{y}$, the standard deviations. The analysis was carried out using the software APSS 1.0.

The spearman correlation (Spearman 1904) was also used. Spearman's rho is given the symbol rs. In case of two variables $X$ and $Y$, the rank of each variable is determined by ordering the values from low to high, or from 
Example of Application on the first Physical Factor of Drought (Number 1),

-The total respondents: $\mathrm{n}=290$

-Example of responses: For this Indicator, According to the respondents data, 16 persons estimated low impact, 60 Middle, 117 High, and 252 Very High Impact as mentioned hereafter.

\begin{tabular}{|c|c|c|c|c|}
\hline \multirow{2}{*}{ Impacting factor } & \multicolumn{4}{|c|}{ Degree of impact } \\
\cline { 2 - 5 } & Low (1) & Middle (2) & High (3) & Very High (4) \\
\hline Groundwater Scarcity & 16 & 60 & 117 & 88 \\
\hline
\end{tabular}

The Likert calculating is as follows:

- 16 (Number of respondents)* 1 (Low degree) : $16^{*} 1=16$ (16 persons Low impact)

- 60 persons replied Middle Impact, which gives : $60 * 2=120$ (160 Middle Impact

- 117 persons replied High Impact

- 88 persons replied Very High Impact

$117 * 3=351$ (351 High Impact)

Impact)

The total score $=16+120+351+352=839$.

Points $=839 / 290=2.8933=3$

The result shows that the interviewees trend and direction is High (3).

Groundwater scarcity is the high impact factor of Drought because this indicators falls

within the range of High Impact.

Fig. 3 Example explaining the use of Likert scale approach

high to low. The difference in the rank on the two variables, and given the symbol $\sum D i, n$ number cases of each variable.

$$
r_{s}=1-\frac{6 \sum D_{i}^{2}}{n\left(n^{2}-1\right)}
$$

\section{Variables used to evaluate vulnerability to drought and desertification}

The proposed framework was designed to enable decision makers and researchers to understand and predict the suitable response for anti-desertification and anti-drought managements. Given the heterogeneity of the factors that affect these two phenomena, there was a need to develop this multidisciplinary method. Such methods are capable of giving a fairly detailed global view of the environmental vulnerability. These methods can support the policymakers with a holistic assessment of the local. The approach categorizes five components or sub-index, which are Climate, Physical factors, Biological factors, Social factors, and Access to services. Table 1 depicts the selected variables of drought and desertification and the common variables related to both drought and desertification in Draa Valley. The total number of questions was 27, from which 17 common questions were selected. These later include the following factors: Groundwater Scarcity (1), Surface water scarcity (2), Water Salinity (3), Soil salinity (4), Overgrazing (5), Deforestation (6), Bayoud disease (7), Transhumant (8), Population growth (9), Migration (10), Schooling (11), Health service (12), School Service (13), Drinking water Service (14), Electricity Service (15),
Production of organic fertilizers (16), and Seasonal migration (17).

The selection of questions and common variables is the new contributions of this paper. In addition to their obvious relationships with the drought and desertification, these variables selection was based and confirmed during the student brainstorming activity (workshop), which preceded the investigation. The high weight given to the impact of the used variables can prove the relative suitability.

For drought and desertification solutions, two common questions (Production of organic fertilizers and Seasonal migration) and three different questions (Tourism, Safe water, and Diversification of activities) were used as shown in Table 1. These solutions propose the understanding of how local population can adapt to these two phenomena.

\section{Results}

\section{General information about desertification and drought in Draa valley}

According to Fig. 4a, 79\% of the interviewed young person classify drought as the first factor and $67 \%$ classify desertification in the second class. Ninety two \% of the respondents classify flood in the third position. As conclusion, according to this study, the area is currently suffering from drought followed by desertification, and then flood.

Concerning the desertification causes, since the eighties, Kassas (1987) asked about the ultimate cause of desertification. The current study (Fig. 4b) shows that the common origin is in first position (both natural and human are in the origin of desertification). In fact, the response for natural factor is divided between $43.1 \%$ as 
Table 1 The selected variables of drought and desertification in Draa Valley. The last column presents all the variables which are common to the two phenomena

\begin{tabular}{|c|c|c|c|c|}
\hline \multicolumn{2}{|c|}{ Desertification variables } & \multicolumn{2}{|l|}{ Drought variables } & \multirow[t]{2}{*}{ Common indicators } \\
\hline General & Frequent phenomena & General & Frequent phenomena & \\
\hline & Desertification Causes & & Land degradation & \\
\hline \multirow[t]{3}{*}{ Climate } & Temperature & - & - & \\
\hline & Rainfall & & & \\
\hline & Winds & & & \\
\hline \multirow[t]{5}{*}{ Physical factors } & Groundwater Scarcity & Physical factors & Groundwater Scarcity & $*(1)$ \\
\hline & Surface water scarcity & & Surface water scarcity & $*(2)$ \\
\hline & Water Salinity & & Water Salinity & $*(3)$ \\
\hline & Soil salinity & & Soil salinity & $*(4)$ \\
\hline & - & & Sand silting & \\
\hline \multirow[t]{3}{*}{ Biological factors } & Overgrazing & Biological factors & Overgrazing & $*(5)$ \\
\hline & Deforestation & & Deforestation & $*(6)$ \\
\hline & Bayoud disease & & Bayoud disease & $*(7)$ \\
\hline \multirow[t]{6}{*}{ Social factors } & Transhumants & Social factors & Transhumants & $*(8)$ \\
\hline & Population growth & & Population growth & $*(9)$ \\
\hline & Migration & & Migration & * (10) \\
\hline & Schooling & & Schooling & $*(11)$ \\
\hline & Fertilizer use & & Gender & \\
\hline & - & & Psycological & \\
\hline \multirow[t]{5}{*}{ Access to services } & Health & Access to services & Health & $*(12)$ \\
\hline & School & & School & * (13) \\
\hline & Drinking water & & Drinking water & $*(14)$ \\
\hline & Electricity & & Electricity & $*(15)$ \\
\hline & - & & Exploitation of forests and pastures & \\
\hline \multirow[t]{4}{*}{ Consequences } & Irrigation canals and seguias & Economy & Revenue Reduction & \\
\hline & Settlements & & Yield reduction & \\
\hline & Roads and tracks & & Livestock reduction & \\
\hline & & & Land use (crops) & \\
\hline \multirow[t]{4}{*}{ Solutions } & Production of organic fertilizers & Solutions & Production of organic fertilizers & $*(16)$ \\
\hline & Seasonal migration & & Seasonal migration & $*(17)$ \\
\hline & Tourism & & Safe water & \\
\hline & & & Diversification of activities (tourism, crafts) & \\
\hline
\end{tabular}

Asterisk $\left(^{*}\right)$ and Numbers from 1 to 17 indicate the number and order of the common indicators to the two phenomena (Drought and desertification)

the first factor and $45 \%$ the third and $12 \%$ in the second position. The response for human factor is divided between $35 \%$ as first factor and $51.2 \%$ the third and $10 \%$ in the second position. Regarding the common factor is divided between $71 \%$ the first factor and $21 \%$ the third and $8.3 \%$ in the second position.

\section{Specific impact factors of desertification and drought in Draa valley}

The Likert scale data analysis allowed measuring the young people's attitude and knowledge towards drought and desertification phenomena. We used 29 questions and selected 17 common questions that involve the choice of one response of the following: Low, Middle, High, and Very High impact. The results on drought common variables (Table 2) depict that the sample reveals a high impact of factors of Groundwater Scarcity (1), Surface water scarcity (2), Water Salinity (3), Deforestation (6), Migration (10), Drinking water (Service) (14), \& Production of organic fertilizers (16). However, Soil salinity (4), Overgrazing (5), Bayoud disease (7), Transhumant (8), Population growth (9), Schooling (11), Health service (12), School Service (13), Electricity (Service) (15), \& Seasonal migration (17) show an 

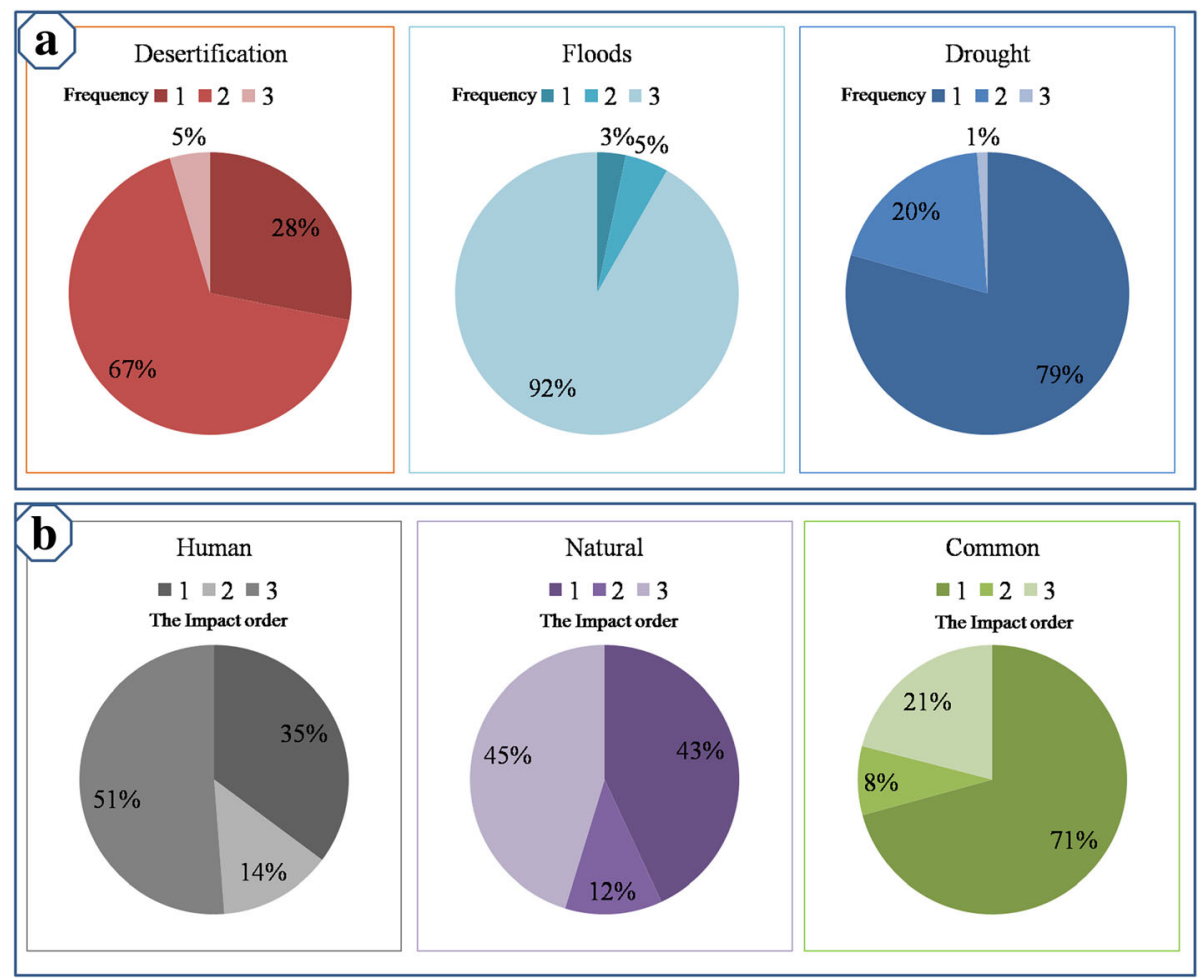

Fig. 4 a Drought and desertification frequency; $\mathbf{b}$ desertification causes

Table 2 Summary of the responses on drought common variables in Draa Valley

\begin{tabular}{|c|c|c|c|c|c|c|c|c|c|c|}
\hline Variables & Very high & High & Middle & Low & Sample & Data \% & Arithmetic average & Standard deviation & $\%$ & Sample Direction \\
\hline 1 & 88 & 117 & 60 & 16 & 281 & 96 & 2.99 & 0.87 & 74.75 & High \\
\hline 2 & 77 & 83 & 64 & 51 & 275 & 94 & 2.68 & 1.07 & 67 & High \\
\hline 3 & 53 & 92 & 107 & 37 & 289 & 99 & 2.56 & 0.93 & 64 & High \\
\hline 4 & 31 & 88 & 112 & 40 & 271 & 92 & 2.41 & 0.87 & 60.25 & Middle \\
\hline 5 & 29 & 60 & 104 & 86 & 279 & 92 & 2.11 & 0.96 & 52.75 & Middle \\
\hline 6 & 83 & 96 & 42 & 33 & 254 & 87 & 2.9 & 1 & 72.5 & High \\
\hline 7 & 76 & 113 & 63 & 110 & 362 & 94 & 2.43 & 1.13 & 60.75 & Middle \\
\hline 8 & 22 & 54 & 110 & 103 & 289 & 99 & 1.98 & 0.92 & 49.5 & Middle \\
\hline 9 & 43 & 93 & 104 & 47 & 287 & 98 & 2.46 & 0.94 & 61.5 & Middle \\
\hline 10 & 73 & 80 & 89 & 44 & 286 & 98 & 2.64 & 1.02 & 66 & High \\
\hline 11 & 49 & 66 & 117 & 50 & 282 & 96 & 2.4 & 0.97 & 60 & Middle \\
\hline 12 & 58 & 74 & 85 & 69 & 286 & 98 & 2.42 & 1.06 & 60.5 & Middle \\
\hline 13 & 42 & 73 & 121 & 37 & 273 & 93 & 2.44 & 0.91 & 61 & Middle \\
\hline 14 & 96 & 76 & 82 & 28 & 282 & 96 & 2.85 & 1 & 71.25 & High \\
\hline 15 & 32 & 90 & 104 & 57 & 283 & 97 & 2.34 & 0.92 & 58.5 & Middle \\
\hline 16 & 59 & 89 & 85 & 51 & 284 & 97 & 2.55 & 1.01 & 63.75 & High \\
\hline 17 & 39 & 84 & 91 & 69 & 283 & 97 & 2.33 & 0.99 & 58.25 & Middle \\
\hline \multicolumn{7}{|c|}{ General average } & 2.5 & 1.01 & 62.5 & High \\
\hline
\end{tabular}


average impact that accelerate drought. The general average shows a high trend of high direction (62.5\%).

Land degradation and livestock reduction (Fig. 5) are other aspects of drought impacts explored in the study survey as mentioned in Table 1 (see general and Economy variables of 29 questions of drought). Likert technique indicates a high direction of these two supplementary variables, which means that drought have a high impact on land degradation and on livestock reduction.

Regarding the desertification phenomenon, the Likert analysis depicts (Table 3 ) that the sample reveals a high impact factor of Groundwater Scarcity (1), Surface water scarcity (2), Deforestation (6), Bayoud disease (7), Migration (10), and Drinking water (Service) (14). However, Water Salinity (3), Soil salinity (4), Overgrazing (5), Transhuments (8), Population growth (9), Schooling (11), Health service (12), School Service (13), Electricity (Service) (15), Production of organic fertilizers (16), \& Seasonal migration (17) show an average impact that accelerate the desertification processes. The general average shows a high trend of middle direction (62\%).

In order to facilitate comparison, data of the respondents mentioned in both Tables 2 and 3 can be represented schematically in the form of profiles (Fig. 6).

At first glance, the two profiles (Fig. 6) show certain symmetry in the shape (drought and desertification). This gives an idea of the relation of these two phenomena. This type of profiles can be replicated in other areas for other natural or man-made hazards such as floods, sandstorms, and locust attacks. Figure 6 depicts that services such as level of education (schooling), health, drinking water, electricity, are also important variables linked to drought and desertification. Population with low services is impacted by these two phenomena and in turn can accelerate their impacts on resources. Additionally, the sand dune advancement, overgrazing, Bayoud disease, transhumance, soil and water salinity, and deforestation constitute among the most important impacts.

\section{Correlations between desertification and drought (correlation on the different degrees)}

The use of statistical relationship between desertification and drought variables depicts a very strong correlation regarding those who responded a very high impact for the two phenomena (Fig. 7). This means that drought and desertification cause usually the same disturbance, which lead to highlight their relationships.

\section{General direction sample for the two phenomena}

Following the Pearson correlation there is a strong positive relationship $(r=0.633)$ between the two phenomenon. However for the spearman correlation (independents variables) a very strong positive relationship was found $\left(r_{s}=0.996\right.$, perfect correlation). This statistical analysis indicates that there is a very strong link between land degradation, desertification and drought. However, Kassas (1987) reported that drought does not necessarily lead to desertification.

What needs to be done to mitigate the impact of the studied phenomena? The proposed solutions for the desertification were the production of organic fertilizers, the exploitation of touristic attractive sites, and the seasonal migration of young persons. Water shortage was the important reason of the migration in the most affected villages like M'Hamid (most downstream zone of the study area). Water shortage impacts also the rangelands and the associated ecosystem services (pasture, animal production, groundwater, esthetic services), which raise the forage price and influence local population.

There are important relationships between these two phenomena and ecosystem services of water and also of soil. With the increase in the frequency of drought and desertification, water and soil resources can constitute the main problems affecting this region. This can threaten the socio-economic well-being and then the existence of the oasis ecosystem.

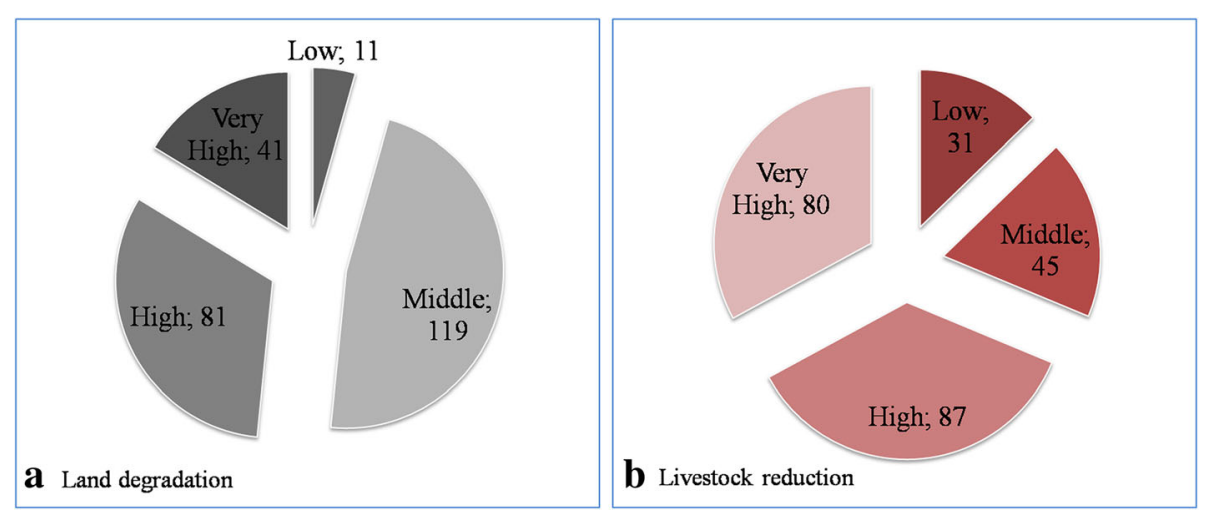

Fig. 5 Land degradation (a) and livestock reduction (b) variables of Drought (Supplementary variables) 
Table 3 Summary of the responses on desertification common variables in Draa Valley

\begin{tabular}{|c|c|c|c|c|c|c|c|c|c|c|}
\hline Variables & Very high & High & Middle & Low & Sample & Data \% & Arithmetic average & Standard deviation & $\%$ & Sample Direction \\
\hline 1 & 80 & 90 & 62 & 50 & 282 & 96 & 2.71 & 1.06 & 67.75 & High \\
\hline 2 & 73 & 94 & 89 & 30 & 286 & 98 & 2.73 & 0.96 & 68.25 & High \\
\hline 3 & 53 & 75 & 111 & 43 & 282 & 96 & 2.49 & 0.96 & 62.25 & Middle \\
\hline 4 & 35 & 94 & 103 & 46 & 278 & 95 & 2.42 & 0.91 & 60.5 & Middle \\
\hline 5 & 52 & 75 & 80 & 56 & 263 & 90 & 2.47 & 1.03 & 61.75 & Middle \\
\hline 6 & 88 & 109 & 65 & 21 & 283 & 97 & 2.93 & 0.91 & 73.25 & High \\
\hline 7 & 73 & 101 & 75 & 33 & 282 & 96 & 2.76 & 0.97 & 69 & High \\
\hline 8 & 23 & 61 & 112 & 83 & 279 & 95 & 2.09 & 0.92 & 52.25 & Middle \\
\hline 9 & 38 & 73 & 111 & 61 & 283 & 97 & 2.31 & 0.96 & 57.75 & Middle \\
\hline 10 & 50 & 96 & 75 & 45 & 266 & 91 & 2.57 & 0.98 & 64.25 & High \\
\hline 11 & 47 & 78 & 98 & 63 & 286 & 98 & 2.38 & 1 & 59.5 & Middle \\
\hline 12 & 64 & 74 & 74 & 81 & 293 & 100 & 2.41 & 1.11 & 60.25 & Middle \\
\hline 13 & 31 & 82 & 110 & 52 & 275 & 94 & 2.33 & 0.91 & 58.25 & Middle \\
\hline 14 & 55 & 90 & 98 & 45 & 288 & 98 & 2.54 & 0.97 & 63.5 & High \\
\hline 15 & 30 & 58 & 121 & 73 & 282 & 96 & 2.16 & 0.93 & 54 & Middle \\
\hline 16 & 45 & 76 & 86 & 79 & 286 & 98 & 2.3 & 1.04 & 57.5 & Middle \\
\hline 17 & 48 & 92 & 107 & 44 & 291 & 99 & 2.49 & 0.94 & 62.25 & Middle \\
\hline \multicolumn{7}{|c|}{ General average } & 2.48 & 1 & 62 & Middle \\
\hline
\end{tabular}

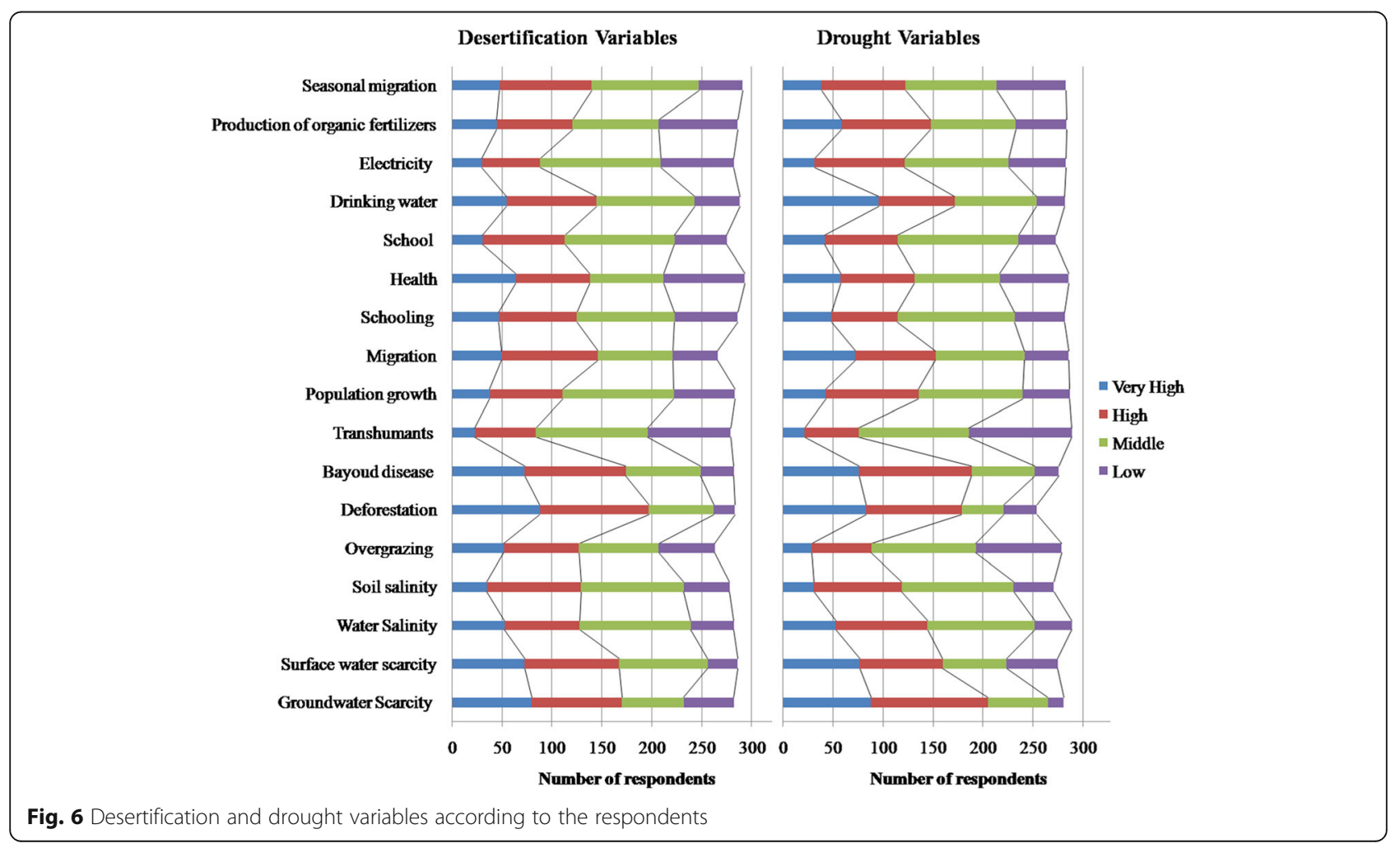




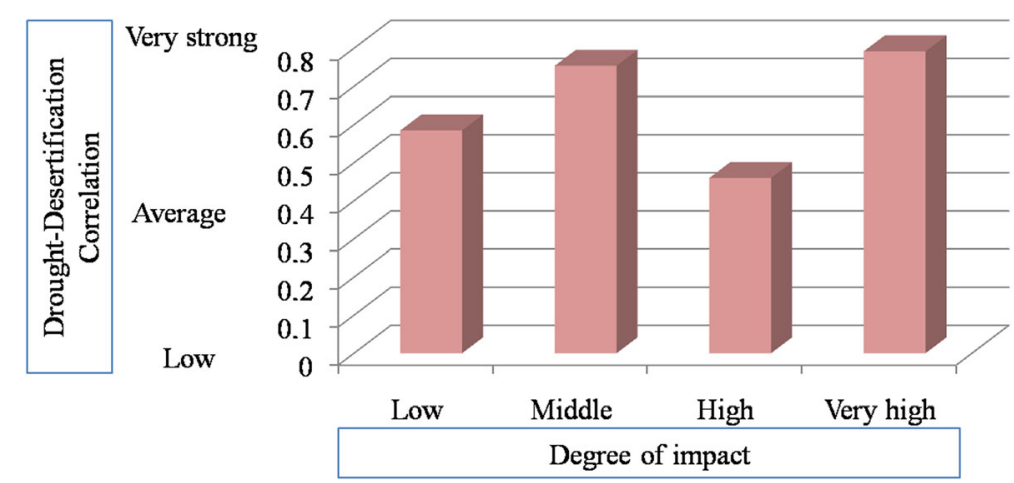

Fig. 7 Pearson Correlation between desertification and drought for the 17 variables, with $n=17$; significance $(a=0.05)$, Degree of Liberty: 15. Interpretation from left to right: Average correlation Strong correlation Average correlation Very Strong correlation

\section{Discussion}

Globally, climate change and human impacts are the main stresses affecting natural resources (especially water and soil). This impact has been confirmed since 20 years in the Mediterranean basin by Conacher and Sala (1998). Drought and desertification are among the main consequences of these stresses. The phenomena (drought and desertification) are closely related, and threaten mainly people who are dependent on resources (Stringer et al. 2009). The identification and quantification of the impact factors constitutes a key element to understand their processes. In this context, Salvati et al. (2013) reported that the identification of variables is a crucial step to evaluate land degradation and support policy making.

In this paper several impact factors were identified and classified. Some variables are associated with soil, some with water, and other with biodiversity. These three elements are the main pillars of an ecosystem. In the oases, these elements are severely threatened by climate change, drought, and desertification. The proposed approach (Community-based Risk Reduction Framework) helps to simplify the complex relationship between the two phenomena and between individual variables within mainly four classes, physical, biological, social, access to services factors.

For the relationships between drought and desertification, there are differences among the respondents in components; some had the opinion that drought and desertification have low and high socio-ecological impacts, and strong similarity between respondents in components said that drought and desertification had middle and very high impacts. This leads to highlight their relationships, which is in accordance with the findings of several studies at global scale (Le Houérou 1996), in the Sahel countries (Giannini et al. 2008), in Nigerian environment (Olagunju 2015), from the West African Sahel (Nicholson et al. 1998), and in Morocco.
For the impact of drought on desertification, the study result shows that drought have a high impact on land degradation. This corroborate the findings from the study of Long and Gerbe (2005), which reported that water scarcity (effects of drought) influences greatly the primary production, causing degradation of the vegetal cover and then in turn affect the soil layers (Poor soil properties). The importance of water and soil as fundamental to ecosystem services in Draa valleys, accelerate the vulnerability to drought and desertification.

In the Climate change trends, Le Houérou (1996), reported globally an increase of $0.5^{\circ} \mathrm{C}$ in temperature in the past century. The IPCC reports stated an increasing trend in temperature and a decrease precipitation in the future.

Endogenous knowledge can be used to mitigate the consequences of both desertification and drought. The khattaras are among the most important heritage in terms of mitigation of drought and aridity. The khattaras is a traditional system which allows using groundwater. Several hundreds of khattaras were found in Draa-Tafilalet region including the studied area. Khattaras creation and rehabilitation can be a solution in dry period. Land degradation or scientifically desertification is due mainly to anthropogenic factors and accelerated by climate change and drought. Drought triggers the desertification, and also the desertification can influence the drought by reducing the water soil content (surface moisture).

Using the numerical acquired data from the archives of IMPETUS Project, the same trend is evident in changing precipitation (Fig. 8a), water storage in dams (Fig. 8b), and condition of land crop (Fig. 8c) were recorded in the Draa Valley. This validates the relationship between drought, water and vegetation cover (soil quality and productivity) found in this investigation. As explored in Fig. 8, climatic and hydrological parameters are deeply connected. The correlation between these two types of variables leads to mitigate the impact of the drought (Mishra and Singh 2010). 

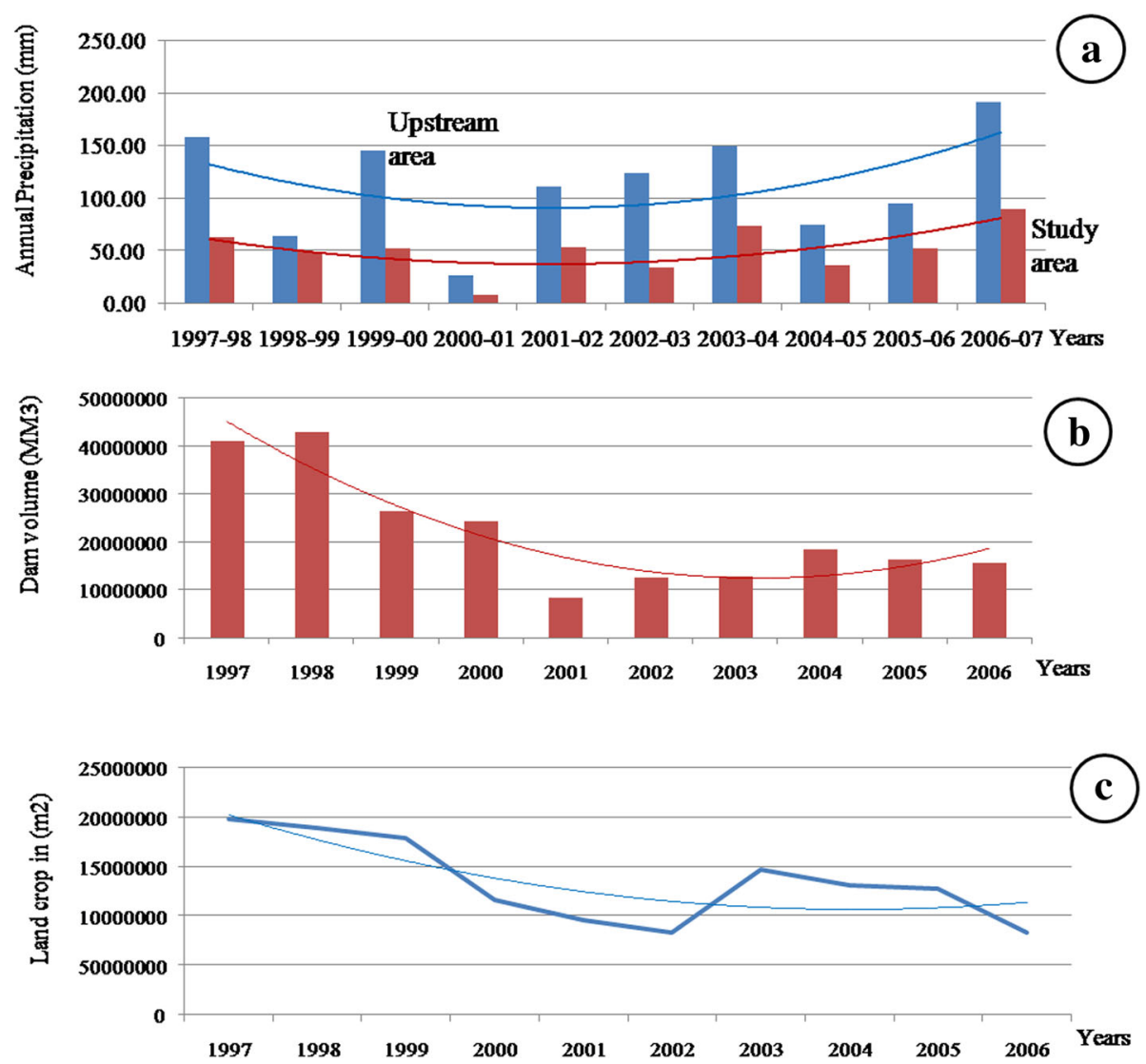

Fig. 8 Drought, water availability and land productivity associations in ten years. $\mathbf{a}$ annual precipitation; $\mathbf{b}$ dam water volume; and $\mathbf{c}$ land crop in Draa Valley

As mentioned above, drought accelerates desertification process, which affects the production of main crops and the animals' numbers in the study area. This situation is considered as the starting point of the conflicts on the resources, migration, illiteracy, and the poverty dispersion.

In addition, oasis ecosystem management requires the integration of several sectors (social, economic, and ecologic). The outputs of this paper can serve as an important data base for future scientific and local development studies.

\section{Recommendations}

- Due to the importance of socio-economic component, securing a minimal level of education, health, water, electricity, and other services for the local population can improve their well being, and consequently the decrease pressure.

- Protect the natural resources by stabilizing sand dune, and the afforestation are the physical measures that must be taken,

\section{Conclusion}

The paper provides an analysis of the socio-economical, physical, biological impacts of drought and desertification in Draa Valley (South of Morocco). This valley is among the most deserted areas, where drought is frequent and desertification is the first environmental threat in the area. More than $70 \%$ of local population depend on the agriculture sector is vulnerable to drought and desertification. The importance and the complexity of the challenges (ecologic, social, and economic), raised the need for further studies on that subject. A set of variables and common variables of drought and desertification can help to understand their impacts on well-being and their relationships. The findings can be used to provide some insights in order reduce the associated risks. The main results show that the studied area is currently suffering from drought followed by desertification and then floods. The natural and human factors are both in the origin of desertification. The study indicates also a very strong link between desertification and drought which is in accordance with several studies worldwide. 


\section{Additional file}

Additional file 1: Questionnaire on Desertification in Middle Draa Valley. (DOCX $41 \mathrm{~kb}$ )

\section{Abbreviations}

APSS: Arab processor in social statistics software; CRRT: Community-based Risk Reduction Framework; GDP: Gross domestic product

\section{Acknowledgements}

Many thanks go to the student's parents association, Ibn El Mahdi Eljirari, and Imam Ali high-schools, students, and staff of Bni Zouli (Zagora, Morocco) for participating and supporting this study.

\section{Funding}

No funding was received.

\section{Availability of data and materials}

Data included in the manuscript.

\section{Authors' contributions}

AK carried out the survey, wrote the manuscript, developed the theoretical formalism, and performed the analytic calculations. The author read and approved the final manuscript.

\section{Ethics approval and consent to participate}

I confirm that the study complies with all regulations and confirmation that informed consent was obtained.

\section{Competing interests}

The author declares that he has no competing interests.

\section{Publisher's Note}

Springer Nature remains neutral with regard to jurisdictional claims in published maps and institutional affiliations.

Received: 9 October 2018 Accepted: 12 March 2019

Published online: 03 April 2019

\section{References}

Anderegg, L.D., W.R. Anderegg, and J.A. Berry. 2013. Not all droughts are created equal: Translating meteorological drought into woody plant mortality. Tree Physiology 33 (7). https://doi.org/10.1093/treephys/tpt044.

Benmohammadi, A., L. Benmohammadi, J.L. Ballais, and J. Riser. 2000. Analysis of anthropic and natural interrelations: Their impact on the recrudescence of the phenomena of sand deposition and desertification in south East Morocco (Drâa valley and Ziz valley). Sécheresse 11 (4): 297-308 Available on https://www.cabdirect.org/cabdirect/abstract/20013044152.

Chelleri, L., Minucci, G., Ruiz, A., \& Karmaoui, A. 2014. Responses to Drought and Desertification in the Moroccan Drâa Valley Region: Resilience at the Expense of Sustainability?. International Journal of Climate Change: Impacts \& Responses, 5(2)

Christian, B.A., and P.S. Dhinwa. 2018. Long term monitoring and assessment of desertification processes using medium \& high resolution satellite data. Applied Geography 97: 10-24. https://doi.org/10.1016/j.apgeog.2018.04.010.

Conacher, A.J., and M. Sala, eds. 1998. Land degradation in Mediterranean environments of the world. Chichester: Wiley.

Coppock, D.L., ed. 1994. The Borana plateau of southern Ethiopia: synthesis of pastoral research, development, and change, 1980-91. Vol. 5. ILRI (aka ILCA and ILRAD). The International Livestock Research Institute (ILRI), Nairobi.

Fallahzade, J., and M.A. Hajabbasi. 2012. The effects of irrigation and cultivation on the quality of desert soil in Central Iran. Land Degradation \& Development 23 (1): 53-61. https://doi.org/10.1002//dr.1049.

Ge, X., Y. Li, A.E. Luloff, K. Dong, and J. Xiao. 2015. Effect of agricultural economic growth on sandy desertification in Horqin Sandy land. Ecological Economics 119: 53-63. https://doi.org/10.1016/j.ecolecon.2015.08.006.

Genxu, W., and C. Guodong. 1999. Water resource development and its influence on the environment in arid areas of China-The case of the Hei River basin.
Journal of Arid Environments 43 (2): 121-131. https://doi.org/10.1006/jare. 1999.0563.

Giannini, A., M. Biasutti, and M.M. Verstraete. 2008. A climate model-based review of drought in the Sahel: Desertification, the re-greening and climate change. Global and Planetary Change 64 (3): 119-128. https://doi.org/10.1016/j. gloplacha.2008.05.004.

Gong, L., Q. Ran, G. He, and T. Tiyip. 2015. A soil quality assessment under different land use types in Keriya river basin, southern Xinjiang, China. Soil and Tillage Research 146: 223-229. https://doi.org/10.1016/j.still.2014.11.001.

Greene, C. 2018. Broadening understandings of drought-the climate vulnerability of farmworkers and rural communities in California (USA). Environmental Science \& Policy 89: 283-291. https://doi.org/10.1016/j.envsci.2018.08.002.

Jiang, P., L. Cheng, M. Li, R. Zhao, and Q. Huang. 2014. Analysis of landscape fragmentation processes and driving forces in wetlands in arid areas: A case study of the middle reaches of the Heihe River, China. Ecological Indicators 46: 240-252. https://doi.org/10.1016/j.ecolind.2014.06.026.

Karanja Ng'ang'a, S., E.H. Bulte, K.E. Giller, J.M. McIntire, and M.C. Rufino. 2016. Migration and self-protection against climate change: A case study of Samburu County, Kenya. World Development 84: 55-68. https://doi.org/10. 1016/j.worlddev.2016.04.002.

Karmaoui, A., I. Ifaadassan, A. Babqiai, M. Messouli, and M.Y. Khebiza. 2015b. Analysis of the water supply-demand relationship in the middle Draa Valley, Morocco, under Climate change and socio-economic scenarios. Journal of Scientific Research \& Reports 9. https://doi.org/10.9734/JSRR/2016/21536.

Karmaoui, A., I. Ifaadassan, M. Messouli, and M.Y. Khebiza. 2015c. Sustainability of the Moroccan oasean system (case study: Middle Draa Valley). Global Journal of Technology and Optimization 6: 170. https://doi. org/10.4172/2229-8711.1000170.

Karmaoui, A., A. Karmaoui, A. Karmaoui, Yacoubi, and M. Khebiza. 2014b. A multidisciplinary approach to assess the environmental vulnerability at local scale in context of climate change (pilot study in Upper Draa Valley, South Morocco). Global Journal of Technology and Optimization 6: 167. https://doi. org/10.4172/2229-8711.1000167

Karmaoui, A. A. Karmaoui, A. Karmaoui, Yacoubi, and M. Khebiza. 2015a. Characterization of common environmental indicators of the Moroccan Oasean biome, pilot study in the reserve biosphere of Oases in Southern Morocco. Advances in Research. https://doi.org/10.9734/AIR/2015/19369.

Karmaoui, A., M. Messouli, Y.M. Khebiza, and I. Ifaadassan. 2014a. Environmental vulnerability to climate change and anthropogenic impacts in dryland,(pilot study: Middle Draa Valley, South Morocco). Journal of Earth Science \& Climatic Change S11: 002. https://doi.org/10.4172/2157-7617.S11-002.

Karmaoui, A., M. Messouli, and M. Yacoubi. 2015d. Vulnerability of ecosystem services to climate change and anthropogenic impacts in south East of Morocco (Case study: Drying up of Iriki lake). The International Journal of Climate Change: Impacts and Responses 7 (3): 1835-7156.

Kassas, M. 1987. Drought and desertification. Land Use Policy 4 (4): 389-400.

Kong, W. Sun, O. J., Xu, W., \& Chen, Y. 2009. Changes in vegetation and landscape patterns with altered river water-flow in arid West China. Journal of arid environments, 73(3), 306-313.

Krosnick, Jon A., and S. Presser. 2010. Question and questionnaire design. In Handbook of survey research. Emerald Group Publishing Limited.

Laouina, A. 2006. Gestion durable des ressources naturelles et de la biodiversité au Maroc: Prospective «Maroc 2030». Haut-Commissariat au Plan.

Le Houérou, H.N. 1996. Climate change, drought and desertification. Journal of Arid Environments 34 (2): 133-185.

Lemmen, D.S., and F.J. Warren. 2004. Climate change impacts and adaptation: A Canadian. URI: http://hdl.handle.net/10214/15055.

Li, L., H. Lu, D.R. Tilley, and G. Qiu. 2014. Effect of time scale on accounting for renewable emergy in ecosystems located in humid and arid climates. Ecological Modelling 287: 1-8. https://doi.org/10.1016/j.ecolmodel.2014.05.001.

Likert, R. 1932. A technique for the measurement of attitudes. Archives of psychology, 22 140, 55.

Long, G., and A. Gerbe. 2005. Conceptual, organizational and operational framework of ROSELT/OSS.

Lu, Z., Y. Wei, H. Xiao, S. Zou, J. Ren, and C. Lyle. 2015. Trade-offs between midstream agricultural production and downstream ecological sustainability in the Heihe River basin in the past half century. Agricultural Water Management 152: 233-242. https://doi.org/10.1016/j. agwat.2015.01.022

Mishra, A.K. and V.P. Singh. 2010. A review of drought concepts. Journal of Hydrology 391 (1): 202-216. https://doi.org/10.1016/j.jhydrol.2010.07.012. 
Mittler, R. 2006. Abiotic stress, the field environment and stress combination Trends in Plant Science 11 (1): 15-19. https://doi.org/10.1016/j.tplants.2005. 11.002

Nicholson, S.E., C.J. Tucker, and M.B. Ba. 1998. Desertification, drought, and surface vegetation: An example from the west African Sahel. Bulletin of the American Meteorological Society 79 (5): 815-829. https://doi.org/10.1175/15200477(1998)079<0815:DDASVA>2.0.CO;2.

Olagunju, T.E. 2015. Drought, desertification and the Nigerian environment: A review. Journal of Ecology and The Natural Environment 7 (7): 196-209. https://doi.org/10.5897/JENE2015.0523.

Pearson, K. 1895. Note on regression and inheritance in the case of two parents. Proceedings of the Royal Society of London 58: 240-242 https:// royalsocietypublishing.org/doi/abs/10.1098/rspl.1895.0041.

RADDO. 2011. Lutte contre la désertification: les oasis au péril du changement climatique. Le réseau d'associations oasiennes du Maghreb (RADDO), (http:// www.raddo.org/).

Salvati, L., G. Mancino, E. De Zuliani, A. Sateriano, M. Zitti, and A. Ferrara 2013. An expert system to evaluate environmental sensitivity: A local scale approach to desertification risk. Applied Ecology and Environmental Research 11 (4): 611-627.

Seidel, S.J., S. Rachmilevitch, N. Schütze, and N. Lazarovitch. 2016. Modelling the impact of drought and heat stress on common bean with two different photosynthesis model approaches. Environmental Modelling \& Software 81: 111-121. https://doi.org/10.1016/..envsoft.2016.04.001.

Shen, Q., G. Gao, B. Fu, and Y. Lü. 2014. Soil water content variations and hydrological relations of the cropland-treebelt-desert land use pattern in an oasis-desert ecotone of the Heihe River basin, China. Catena 123: 52-61. https://doi.org/10.1016/j.catena.2014.07.002.

Spearman, C. 1904. The proof and measurement of association between two things. The American Journal of Psychology 15 (1): 72-101. https://doi.org/10. 2307/1412159.JSTOR1412159.

Stringer, L.C., J.C. Dyer, M.S. Reed, A.J. Dougill, C. Twyman, and D. Mkwambisi. 2009. Adaptations to climate change, drought and desertification: Local insights to enhance policy in southern Africa. Environmental Science \& Policy 12 (7): 748-765. https://doi.org/10.1016/j.envsci.2009.04.002.

Tervonen, T., A. Sepehr, and M. Kadziński. 2015. A multi-criteria inference approach for anti-desertification management. Journal of Environmental Management 162: 9-19. https://doi.org/10.1016/j.jenvman.2015.07.006.

Thurstone, L.L. 1928. Attitudes can be measured. American Journal of Sociology 33 (4): 529-554. https://doi.org/10.1086/214483.

Tomasella, J., R.M.S.P. Vieira, A.A. Barbosa, D.A. Rodriquez, M. de Oliveira Santana, and M.F. Sestini. 2018. Desertification trends in the northeast of Brazil over the period 2000-2016. International Journal of Applied Earth Observation and Geoinformation 73: 197-206. https://doi.org/10.1016/j.jag.2018.06.012.

Wang, Y., and X. Yan. 2017. Climate change induced by southern hemisphere desertification. Physics and Chemistry of the Earth, Parts A/B/C 102: 40-47. https://doi.org/10.1016/j.pce.2016.03.009.

Wonkka, C.L., D. Twidwell, T.E. Franz, C.A. Taylor Jr., and W.E. Rogers. 2016. Persistence of a severe drought increases desertification but not woody dieback in semiarid savanna. Rangeland Ecology \& Management 69 (6): 491 498. https://doi.org/10.1016/j.rama.2016.07.005.

Wu, Z., H. Xu, Y. Li, L. Wen, J. Li, G. Lu, and X. Li. 2018. Climate and drought risk regionalisation in China based on probabilistic aridity and drought index. Science of the Total Environment 612: 513-521. https://doi.org/10.1016/j. scitotenv.2017.08.078.

Yang, J., J. Chang, Y. Wang, Y. Li, H. Hu, Y. Chen, et al. 2018. Comprehensive drought characteristics analysis based on a nonlinear multivariate drought index. Journal of Hydrology 557: 651-667. https://doi.org/10.1016/j.jhydrol. 2017.12.055.

Zelnik, Y.R., H. Uecker, U. Feudel, and E. Meron. 2017. Desertification by front propagation? Journal of Theoretical Biology 418: 27-35. https://doi.org/10. 1016/j.jtbi.2017.01.029.

Zhang, D., Q. Zhang, J. Qiu, P. Bai, K. Liang, and X. Li. 2018. Intensification of hydrological drought due to human activity in the middle reaches of the Yangtze River, China. Science of the Total Environment 637: 1432-1442. https://doi.org/10.1016/j.scitotenv.2018.05.121

\section{Submit your manuscript to a SpringerOpen ${ }^{\circ}$ journal and benefit from:}

- Convenient online submission

- Rigorous peer review

- Open access: articles freely available online

- High visibility within the field

- Retaining the copyright to your article

Submit your next manuscript at $\boldsymbol{\nabla}$ springeropen.com 